Proc. Estonian Acad. Sci. Biol. Ecol., 2004, 53, 1, 37-51

\title{
Application of diatom indices in the evaluation of the water quality in Estonian streams
}

\begin{abstract}
Sirje Vilbaste
Institute of Zoology and Botany, Estonian Agricultural University, Riia 181, 51014 Tartu, Estonia; sirje.vilbaste@zbi.ee

Received 8 April 2003, in revised form 11 November 2003

Abstract. Diatom indices, based on the relative abundance of epilithic diatom species, were calculated for 139 river reaches from 21 watercourses using the software OMNIDIA. The applicability of 16 indices used in different European countries as indicators of the ecological status of running water was tested. Trophic degree (oligo-, meso-, eu-, hypertrophic) and water quality class (high, good, moderate, poor, bad) were used in the analysis. Nine of the studied 16 indices (Biological Diatom Index, Descy's Index, Descy \& Coste Diatom Index, Leclercq \& Maquet Index, Schiefele \& Schreiner Index, Sládeček's Index, Specific Pollution Sensitivity Index, Trophic Diatom Index, Watanabe's Index) were considered as promising in Estonia and selected for further investigation.
\end{abstract}

Key words: diatom indices, Estonia, European Union, OMNIDIA software, periphyton, running waters, water quality.

\begin{abstract}
Abbreviations of diatom indices: CEC - Descy \& Coste Diatom Index, Descy - Descy's Index, EPI-D - Diatom-based Eutrophication/Pollution Index, GDI - Generic Diatom Index, $\mathrm{H}^{\prime}-$ ShannonWeaver Diversity Index, I - Evenness Index, IBD - Biological Diatom Index, IDAP - Artois-Picardie Diatom Index, L-M - Leclercq \& Maquet Index, Rott - Rott's Index, SHE - Schiefele \& Schreiner Index, SLA - Sládeček's Index, SPI - Specific Pollution Sensitivity Index, TDI - Trophic Diatom Index, WAT - Watanabe's Index.
\end{abstract}

\section{INTRODUCTION}

Diatoms have been used extensively in investigations on monitoring water quality for a long time. Round (1991) presented a history of diatom research related to water quality in rivers beginning with the study by Kolkwitz \& Marsson (1908). 
In the last decade, three symposia (Whitton et al., 1991; Whitton \& Rott, 1996; Prygiel et al., 1999) and a number of workshops were dedicated to this topic. In several European countries different diatom indices have been actively used for the monitoring of running waters: Trophic Diatom Index (TDI) in Great Britain (Kelly, 1998); Descy \& Coste Diatom Index (CEC), Descy's Index (Descy), Generic Diatom Index (GDI), and Specific Pollution Sensitivity Index (SPI) in France (Prygiel \& Coste, 1996); CEC and SPI in Belgium and Luxembourg (Descy \& Ector, 1999). The limit values for GDI, SPI, and TDI were worked out for Finnish rivers (Eloranta \& Soininen, 2002).

According to the recently accepted EU Water Framework Directive, the member states of the European Union should identify the ecological status of their water bodies against high quality sites in the undisturbed situation (Directive 2000/60/EC, 2000). For this, a system of the criteria of hydrochemical parameters has been developed for Estonian (an EU candidate member) streams (Loigu \& Leisk, 2001).

It has been shown earlier that water quality in the Estonian rivers is reflected by the epilithic diatom community (Vilbaste, 2001). The present investigation is an attempt to estimate the ecological status of running waters by means of various diatom indices. The aim was to test the sensitivity of diatom indices and their applicability as water quality markers for the Estonian running waters.

\section{MATERIAL AND METHODS}

\section{Sample collection}

Estonia is rich in running waters, the average density of the stream network is $0.72 \mathrm{~km} \mathrm{~km}^{-2}$ (Loopmann, 1979). The material was collected during complex hydrobiological expeditions in 1995-2002. Samples were taken in summer (at the end of June or in July) when the water level was at its minimum and the hydrological characteristics were more stable than during the other seasons. Diatoms were sampled from 6 reaches (one river) in 1995, 7 (one) in 1998, 29 (four) in 1999, 36 (five) in 2000, 24 (three) in 2001, and 37 (eight) in 2002. Altogether 139 river reaches from 21 watercourses were studied (Fig. 1); the Selja River was sampled twice, in 1995 and 2000.

An epilithic diatom sample was obtained from 4-6 cobbles or boulders $($ d. $7-15 \mathrm{~cm})$ free of visible filamentous macroalgal coating. Cobbles were gathered along a transect across the river. At deeper sites samples were taken only to a depth of $0.5 \mathrm{~m}$. The diatom film was separated from the cobbles with a stiff toothbrush. The algal suspension from all gathered cobbles was mixed to obtain a bulky sample. Water samples were taken simultaneously with diatom sampling. 


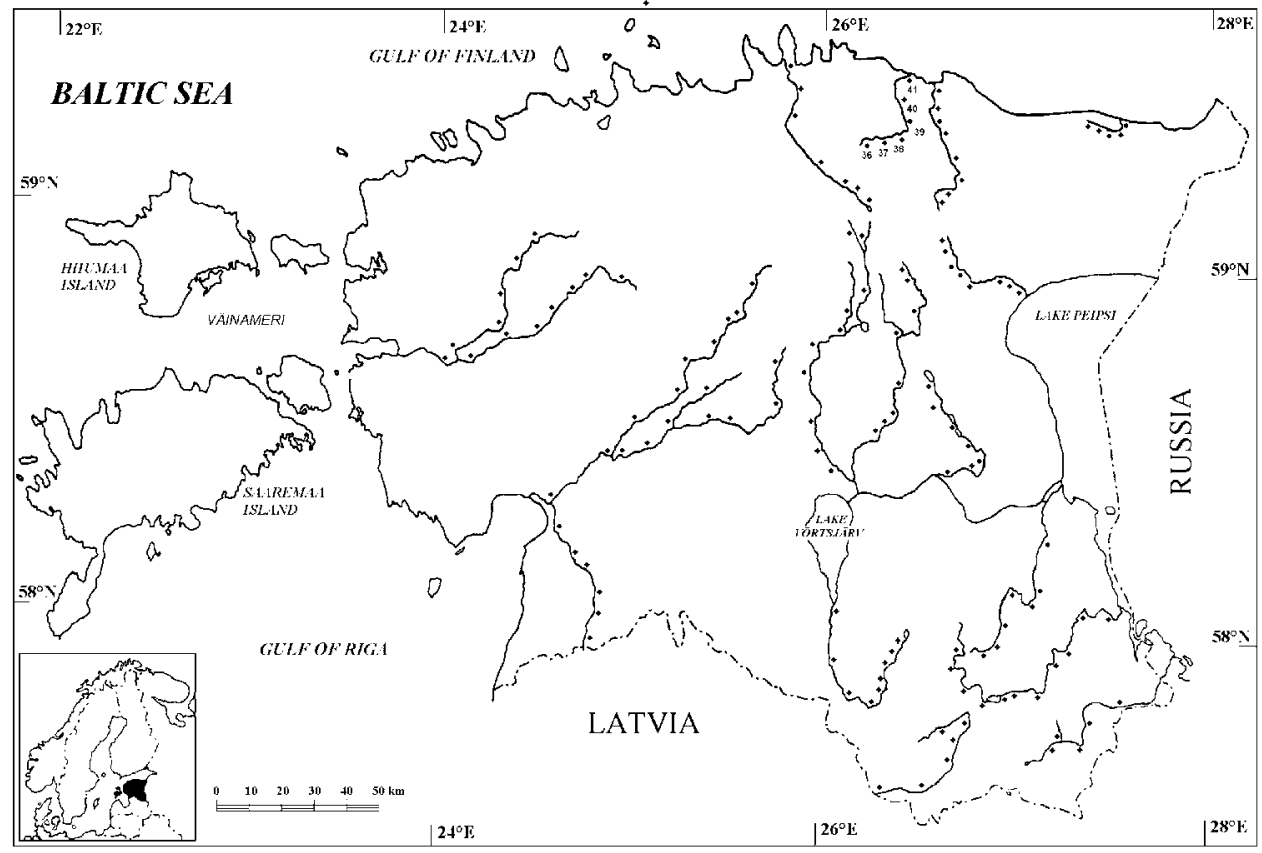

Fig. 1. Map of the studied watercourses with the location of sampling sites. The Selja River is marked with the numbers of river reaches (36-41).

\section{Diatom analyses}

The diatom samples were cleaned by hot acid combustion (Vilbaste et al., 2000; Vilbaste, 2001) and mounted using HYRAX as the medium. From each sample 300-500 valves were identified and counted under a bright field microscope MBL 2000 with a 100 times oil immersion objective. Diatom analyses were made using the latest available version of the OMNIDIA software (Lecointe et al., $1993)$ to calculate 16 different diatom indices (Table 1). The indices were based on variable numbers (from 106 to $\mathrm{ca} 2000$ ) of indicator species clustered into sensitivity classes and indicator value groups. For comparison, the values of 13 indices (SPI, Sládeček's Index (SLA), Descy, Leclercq \& Maquet Index (L-M), GDI, CEC, Schiefele \& Schreiner Index (SHE), Watanabe's Index (WAT), Artois-Picardie Diatom Index (IDAP), TDI, Biological Diatom Index (IBD), Rott's Index (Rott), and Diatom-based Eutrophication/Pollution Index (EPI-D)) were transformed in the program to the scale 0-20. Shannon-Weaver Diversity Index $\left(\mathrm{H}^{\prime}\right)$, Evenness Index (I), and the number of taxa (Tax) were expressed as original values. The STATISTICA software was applied for statistical analyses. 
Table 1. Ranges of diatom indices. Number of samples 139

\begin{tabular}{l|c|c|c|c|c}
\hline \multicolumn{1}{c}{ Diatom index* } & Median & Mean & SD & Min & Max \\
\hline $\mathrm{H}^{\prime}$ & 3.13 & 3.00 & 0.94 & 0.34 & 5.07 \\
$\mathrm{I}$ & 0.66 & 0.62 & 0.16 & 0.12 & 0.92 \\
Tax & 28 & 28 & 8.1 & 7 & 47 \\
SPI & 16.3 & 16.1 & 1.9 & 10.8 & 19.5 \\
SLA & 13.9 & 13.9 & 0.8 & 11.1 & 15.9 \\
Descy & 16.1 & 16.0 & 1.2 & 11.7 & 19.3 \\
L-M & 13.9 & 13.7 & 1.0 & 10.3 & 16.5 \\
GDI & 11.8 & 11.6 & 1.5 & 4.4 & 15.7 \\
CEC & 16.0 & 15.8 & 1.6 & 9.7 & 18.7 \\
SHE & 14.6 & 14.5 & 1.3 & 9.9 & 16.8 \\
WAT & 17.2 & 17.0 & 1.6 & 12.1 & 19.7 \\
IDAP & 14.0 & 13.7 & 2.0 & 6.9 & 19.4 \\
TDI & 14.4 & 14.2 & 2.3 & 6.8 & 19.1 \\
IBD & 14.6 & 14.7 & 1.9 & 10.1 & 17.7 \\
Rott & 14.2 & 14.2 & 0.9 & 10.9 & 16.5 \\
EPI-D & 12.2 & 12.0 & 1.0 & 6.8 & 13.8 \\
& & & & &
\end{tabular}

\section{Environmental variables and water analyses}

Water temperature, $\mathrm{pH}$, concentration of dissolved oxygen, and conductivity were measured in situ in the course of sampling. Water temperature was determined with a mercury thermometer at a depth of $1 \mathrm{~m}$, or on bottom when the stream was not sufficiently deep. The $\mathrm{pH}$ values were obtained using the colorimetric scale GM-58. The content of dissolved oxygen was established with the oxygen meter Marvet Junior 95. Conductivity was measured by a microsensor (MultiLine P4, WTW Wissenschaftlich-Technische Werkstätten GmbH, Weilheim, Germany).

The content of phosphorus and nitrogen compounds in the water was determined in the laboratory using standard methods (Grasshoff et al., 1983). Chemical oxygen demand (COD) was determined by the Dr Lange Sensor Array Photometer LASA ${ }^{\circledR} 20$. The value of biological oxygen demand $\left(\mathrm{BOD}_{5}\right)$ was obtained from the differences between two measurements of dissolved oxygen before and after an incubation period of 5 days in air-tight sample bottles at $20^{\circ} \mathrm{C}$ in dark.

The ratio N/P was calculated as the sum of the mass of inorganic nitrogen $\left(\mathrm{NO}_{3}-\mathrm{N}+\mathrm{NO}_{2}-\mathrm{N}+\mathrm{NH}_{4}-\mathrm{N}\right)$ divided by the mass of free reactive phosphorus (FRP). The level of water trophy in a river reach was estimated by the concentration of total nitrogen (TotN) and total phosphorus (TotP). The scale of Forsberg \& Ryding (1980) was used for TotN, and the content of TotP was estimated according to the 
range developed by Järvekülg (1993). The degree of trophy (oligo-, meso-, eu-, and hypertrophic) was determined from the content of the biogeneous element whose concentration was lower. Water quality classes were determined after Loigu \& Leisk (2001). Six parameters ( $\mathrm{pH}$, percentage of dissolved oxygen saturation, $\mathrm{BOD}_{5}$, TotN, $\mathrm{NH}_{4}-\mathrm{N}$, and TotP) fell into five quality classes: High, Good, Moderate, Poor, and Bad. The quality class of water was established on the basis of the lowest class of the above parameters for a sampling site. The Bad class was only considered if at least two parameters were Bad. If only one parameter fell into Bad class and the others were Poor or better, the water was regarded as Poor.

\section{RESULTS}

\section{Diatom analyses}

Altogether 179 diatom taxa were recorded in this study. The epilithic diatom assemblages were significantly dominated by pennate diatoms. Less than $1 \%$ of the counted cells, belonging to seven species, were centric. The species richness of river reaches varied from 7 to 47 . The list of species included also rare and sporadic taxa: $15 \%$ of the species were encountered only once or twice during the study. Proportionately with valve counts, 16 taxa were responsible for more $80 \%$ of the total cell number (Table 2). The most common species was Achnanthidium

Table 2. List of common (relative abundance (RA) $\geq 1 \%$ ) diatom taxa, their habitats, and RA (\%)

\begin{tabular}{|c|c|c|}
\hline Taxon & Habitat & RA \\
\hline $\begin{array}{l}\text { Achnanthidium minutissimum (Kützing) } \\
\text { Czarnecki }\end{array}$ & Epiphytic + Epilithic & 41.7 \\
\hline Cocconeis placentula Ehrenberg & Epiphytic + Epilithic & 7.3 \\
\hline Amphora pediculus (Kützing) Grunow & Epipelic + Epilithic & 6.7 \\
\hline Navicula tripunctata (O. F. Müller) Bory & Epilithic & 3.6 \\
\hline Navicula cryptotenella Lange-Bertalot & Epipelic & 2.9 \\
\hline $\begin{array}{l}\text { Planothidium lanceolatum (Brébisson) Round \& } \\
\text { Bukhtiyarova }\end{array}$ & Epipsammic + Epilithic & 2.6 \\
\hline Rhoicosphenia curvata (Kützing) Grunow & Epiphytic + Epilithic & 2.2 \\
\hline $\begin{array}{l}\text { Staurosira cf. construens var. venter (Ehrenberg) } \\
\text { Hamilton }\end{array}$ & Epipsammic & 2.1 \\
\hline Cocconeis pediculus Ehrenberg & Epiphytic & 1.6 \\
\hline $\begin{array}{l}\text { Staurosirella pinnata (Ehrenberg) Williams \& } \\
\quad \text { Round }\end{array}$ & Epipsammic & 1.6 \\
\hline Nitzschia palea (Kützing) W. Smith & Epipelic & 1.6 \\
\hline Nitzschia paleacea Grunow & Epilithic & 1.6 \\
\hline Staurosira construens Ehrenberg & Epipsammic & 1.5 \\
\hline Gomphonema parvulum (Kützing) Kützing & Epiphytic + Epilithic & 1.4 \\
\hline Nitzschia dissipata (Kützing) Grunow & Epipelic & 1.4 \\
\hline Meridion circulare (Greville) C. A. Agardh & Epilithic + Epiphytic & 1.0 \\
\hline Total & & 80.8 \\
\hline
\end{tabular}




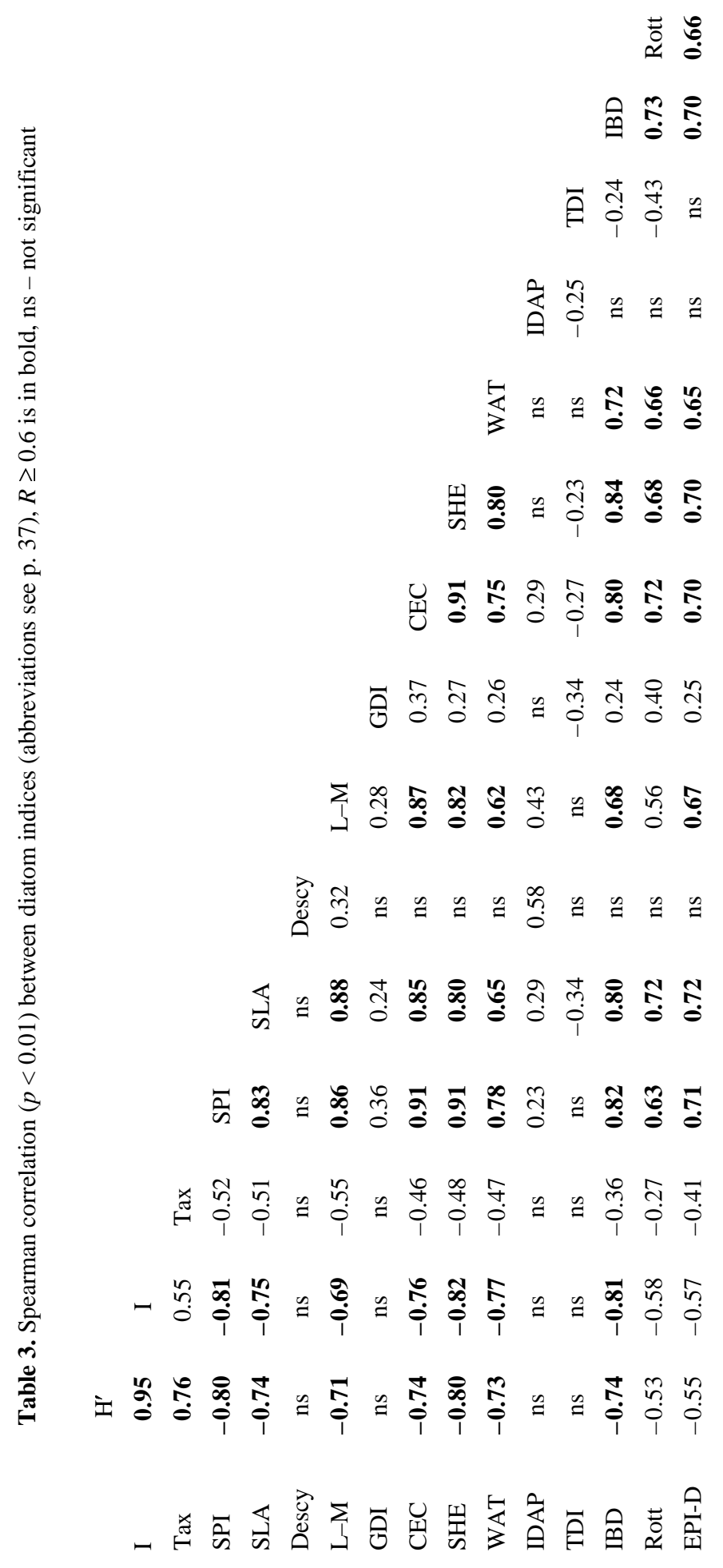


minutissimum. It was registered from all sampling sites, with the mean relative abundance of $41.7 \%$.

The ranges of the diatom indices are presented in Table 1 . The median and the mean were equal for two indices, Tax and SLA; the mean of IBD was higher than its median. For all other 13 indices the median was higher than the mean. The range fluctuation of the values was the largest for IDAP (12.5 units), TDI (12.3), and GDI (11.3); the lowest variability was shown by SLA (4.8), Rott (5.7), and L-M (6.2).

According to correlation analysis (Table 3), two types of indices can be distinguished: (1) indices weakly correlated with the others (Tax, Descy, GDI, IDAP, TDI) and (2) indices very strongly correlated with the others $\left(\mathrm{H}^{\prime}, \mathrm{I}, \mathrm{SPI}\right.$, SLA, L-M, CEC, SHE, WAT, IBD, Rott, EPI-D).

\section{Environmental variables}

The ranges of the environmental variables are shown in Table 4. The median and the mean were equal for $\mathrm{pH}$ (7.8); the median of water temperature, dissolved oxygen, conductivity, and trophy was higher than the mean of these characteristics.

Table 4. Ranges of environmental factors: $\mathrm{T}$ - water temperature, $\mathrm{pH}, \mathrm{Ox}$ - dissolved oxygen, Con - conductivity, TotP - total phosphorus, Tot $\mathrm{N}$ - total nitrogen, $\mathrm{NO}_{3}-\mathrm{N}$ - nitrate nitrogen, $\mathrm{NO}_{2}-\mathrm{N}$ - nitrite nitrogen, $\mathrm{NH}_{4}-\mathrm{N}$ - ammonium nitrogen, $\mathrm{N} / \mathrm{P}$ - ratio of inorganic nitrogen and FRP, $\mathrm{Tr}$ - trophic degree of water ( 1 - oligotrophic, 2 - mesotrophic, 3 - eutrophic, 4 - hypertrophic), $\mathrm{Q}$ - water quality class (1 - High, 2 - Good, 3 - Moderate, 4 - Poor, 5 - Bad), n- number of samples

\begin{tabular}{lcc|c|c|c|c}
\hline \multicolumn{1}{c|}{$\begin{array}{c}\text { Environmental } \\
\text { factor }\end{array}$} & $n$ & Median & Mean & SD & Min & Max \\
\hline $\mathrm{T},{ }^{\circ} \mathrm{C}$ & 139 & 17.3 & 17.1 & 3.7 & 6.3 & 24.3 \\
$\mathrm{pH}$ & 139 & 7.8 & 7.8 & 0.3 & 6.9 & 8.4 \\
$\mathrm{Ox}, \mathrm{mg} \mathrm{L}^{-1}$ & 139 & 9.3 & 9.1 & 2.0 & 3.2 & 17.0 \\
$\mathrm{Con}, \mathrm{mS} \mathrm{m}^{-1}$ & 61 & 496 & 489 & 83 & 289 & 633 \\
$\mathrm{TotP}, \mathrm{mg} \mathrm{m}^{-3}$ & 132 & 55 & 76 & 71 & 8 & 477 \\
$\mathrm{FRP}, \mathrm{mg} \mathrm{m}^{-3}$ & 132 & 26 & 48 & 62 & 0.1 & 409 \\
$\mathrm{TotN}^{-3} \mathrm{mg} \mathrm{m}^{-3}$ & 132 & 1624 & 2082 & 1293 & 610 & 6616 \\
$\mathrm{NO}_{3}-\mathrm{N}, \mathrm{mg} \mathrm{m}^{-3}$ & 132 & 805 & 1372 & 1387 & 30 & 5568 \\
$\mathrm{NO}_{2}-\mathrm{N}, \mathrm{mg} \mathrm{m}^{-3}$ & 132 & 8 & 14 & 18 & 0.5 & 110 \\
$\mathrm{NH}_{4}-\mathrm{N}, \mathrm{mg} \mathrm{m}^{-3}$ & 132 & 20 & 35 & 58 & 0.5 & 431 \\
$\mathrm{COD}^{-1} \mathrm{mg} \mathrm{L}^{-1}$ & 132 & 23 & 24 & 13 & 2 & 70 \\
$\mathrm{BOD}_{5}, \mathrm{mg} \mathrm{L}^{-1}$ & 129 & 2.5 & 2.7 & 0.9 & 0.8 & 6.3 \\
$\mathrm{~N} / \mathrm{P}$ & 132 & 25.8 & 103 & 330 & 3.6 & 2811 \\
$\mathrm{Tr}$ & 132 & 3 & 2.7 & 0.7 & 1 & 4 \\
$\mathrm{Q}$ & 132 & 2 & 2 & 1.1 & 1 & 5
\end{tabular}




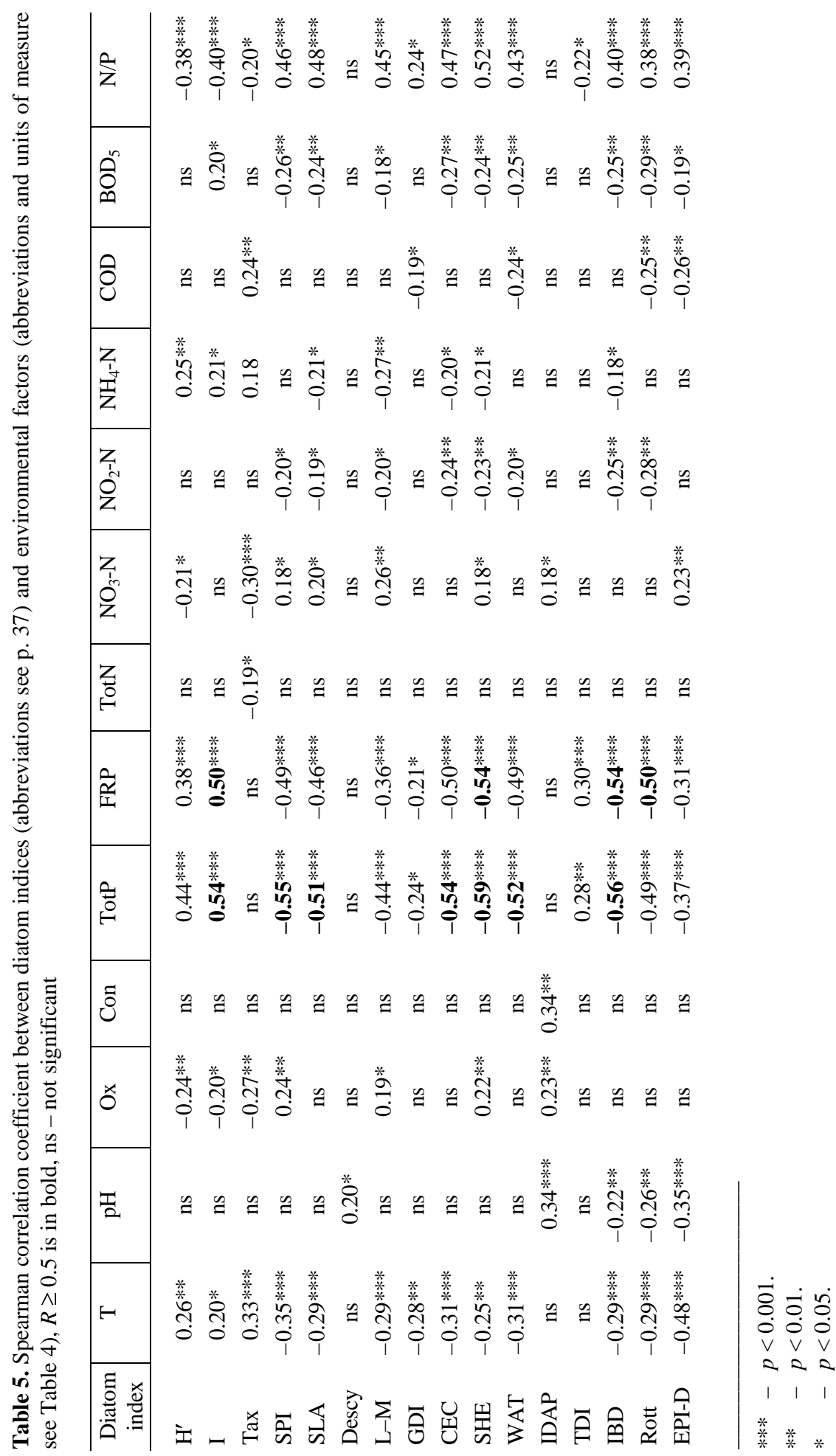


For all other 11 parameters, the median was lower than the mean. Water temperature was the lowest in the upper courses of the spring feeding rivers where it was $<10^{\circ} \mathrm{C}$ even in summer. The value of $\mathrm{pH}$ was quite stable, i.e. all waters were neutral; at the same time, all other variables were highly variable.

The results of correlation analysis for the diatom indices and the environmental variables are presented in Table 5. The diatom indices were relatively weakly correlated with the environmental variables. Descy, TDI, and IDAP revealed particularly weak correlation with each studied variable. A relatively stronger correlation (>0.5) was observed between TotP and the indices I, SPI, SLA, CEC, SHE, WAT, and IBD.

The classification of the water of the studied river reaches in relation to their hydrochemical parameters is presented in Table 6. Water quality was High or Good in $75 \%$ of the studied river reaches (99 of 132). According to the value of $\mathrm{pH}$, the water quality of all rivers was High. There occurred no Poor or Bad waters with regard to $\mathrm{BOD}_{5}$ and no Bad water with regard to $\mathrm{NH}_{4}-\mathrm{N}$. The values of the other three parameters (percentage of oxygen saturation, TotN, and TotP) fell into all of the five quality classes.

Table 6. Numbers of river reaches $(n)$ within each water quality class according to $\mathrm{pH}$, oxygen saturation, $\mathrm{BOD}_{5}$, total $\mathrm{N}, \mathrm{NH}_{4}-\mathrm{N}$, and total $\mathrm{P} ; \mathrm{N}$ - number of river reaches by the total estimation (see Material and Methods)

\begin{tabular}{|c|c|c|c|c|c|}
\hline \multirow[t]{2}{*}{ Parameter } & \multicolumn{5}{|c|}{ Water quality classes } \\
\hline & High & Good & Moderate & Poor & $\mathrm{Bad}$ \\
\hline $\mathrm{pH}$ & $6-9$ & $6-9$ & $6-9$ & $6-9$ & $\langle 6-9\rangle$ \\
\hline$n$ & 132 & 0 & 0 & 0 & 0 \\
\hline Oxygen saturation, $\%$ & $>70$ & $70-60$ & $60-50$ & $50-40$ & $<40$ \\
\hline$n$ & 118 & 7 & 3 & 2 & 2 \\
\hline $\mathrm{BOD}_{5}, \mathrm{mg} \mathrm{L}^{-1}$ & $<3.0$ & $3.0-5.0$ & $5.0-8.0$ & $8.0-10.0$ & $>10.0$ \\
\hline$n$ & 90 & 37 & 2 & 0 & 0 \\
\hline TotN, $\mathrm{mg} \mathrm{m}^{-3}$ & $<2000$ & $2000-3000$ & $3000-4000$ & $4000-5000$ & $>5000$ \\
\hline$n$ & 82 & 25 & 11 & 7 & 7 \\
\hline $\mathrm{NH}_{4}-\mathrm{N}, \mathrm{mg} \mathrm{m}^{-3}$ & $<100$ & $100-300$ & $300-450$ & $450-600$ & $>600$ \\
\hline$n$ & 123 & 7 & 2 & 0 & 0 \\
\hline TotP, $\mathrm{mg} \mathrm{m}^{-3}$ & $<50$ & $50-80$ & $80-120$ & $120-160$ & $>160$ \\
\hline$n$ & 61 & 30 & 19 & 9 & 13 \\
\hline$N$ & 27 & 72 & 14 & 11 & 8 \\
\hline
\end{tabular}




\section{The Selja River}

The Selja River was the only stream that was studied twice. During five years (1995-2000) its water quality had improved considerably (Fig. 2). The load of nitrogen and phosphorus had decreased approximately 1.5 times. The response of the diatom indices to the improved water quality is shown in Fig. 3. All indices except TDI are positively correlated with water quality - a higher value indicates better water quality. The values of most indices followed the same trend in both years and showed that the situation was improving. Only Rott and EPI-D indicated a better status of the water in 1995 compared with 2000.
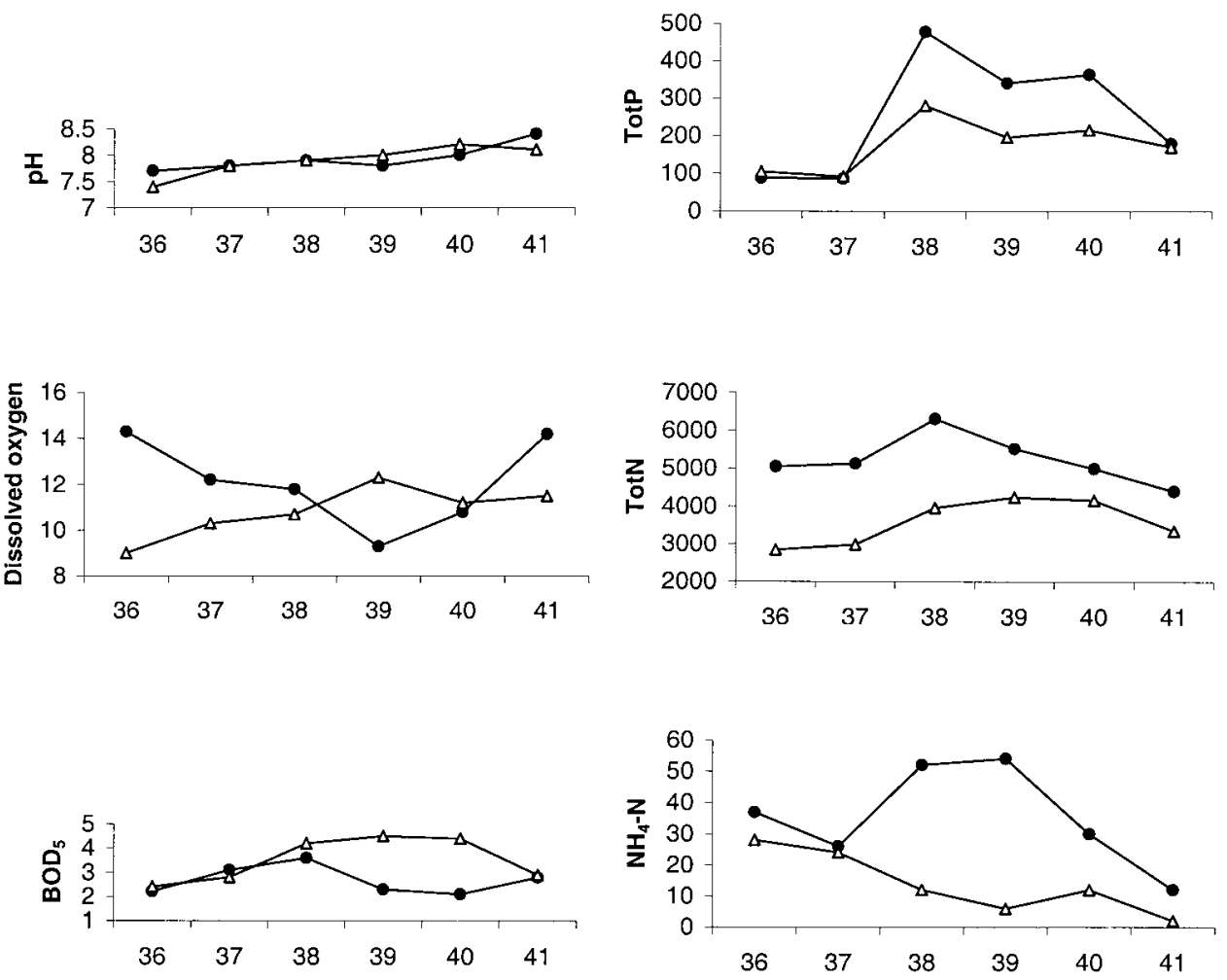

Fig. 2. Water quality parameters ( $\mathrm{pH}$, dissolved oxygen $\left(\mathrm{mg} \mathrm{L}^{-1}\right), \mathrm{BOD}_{5}\left(\mathrm{mg} \mathrm{L}^{-1}\right)$, total $\mathrm{N}\left(\mathrm{mg} \mathrm{m}^{-3}\right)$, $\mathrm{NH}_{4}-\mathrm{N}\left(\mathrm{mg} \mathrm{m}^{-3}\right)$, total $\mathrm{P}\left(\mathrm{mg} \mathrm{m}^{-3}\right)$ of the Selja River in $1995(-\bullet)$ and in $2000\left(-\Delta_{-}\right)$. 36-41, river reaches (see Fig. 1). 

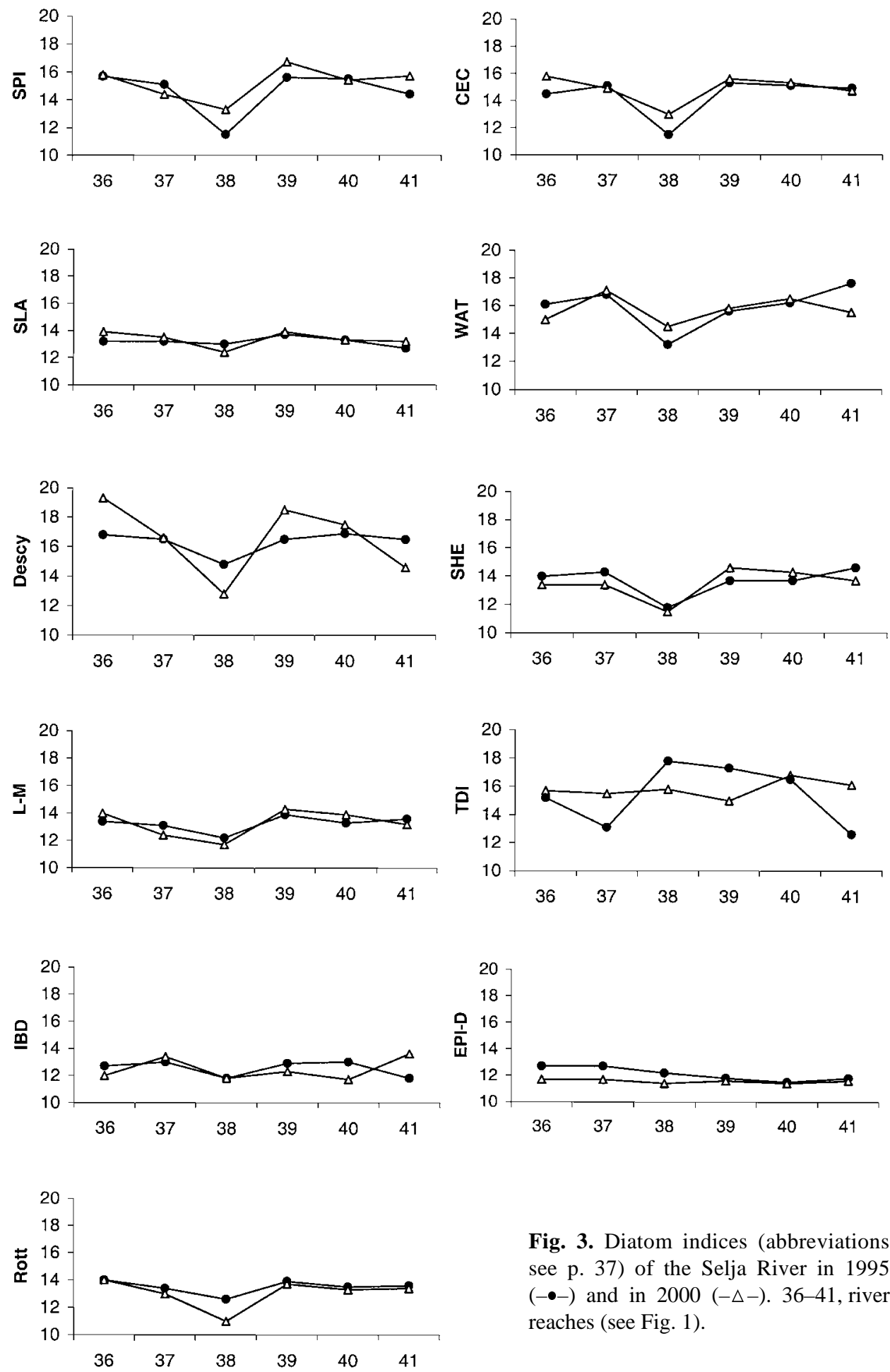

Fig. 3. Diatom indices (abbreviations see p. 37) of the Selja River in 1995 $(--)$ and in $2000(-\triangle-)$. 36-41, river reaches (see Fig. 1). 


\section{DISCUSSION}

Microphytobenthic primary producers use dissolved nutrients directly from water. The composition and structure of periphytic diatom assemblages are formed as a consequence of biological response to water quality over time. An occasional water analysis can give only a rough estimation of the average nutrient level and therefore the environmental factors measured simultaneously with the sampling of diatoms do not often correlate well with the diatom indices (Table 5). Round (1991) too emphasized a low correlation between the biological indices and the chemical parameters of the water.

According to the classification of Loigu \& Leisk (2001), there exists a whole spectrum (five quality classes) of waters in the Estonian streams, from High to Bad (Table 6). However, in this study the Poor and Bad waters were usually differentiated only on the basis of TotP and/or TotN. Diatoms can tolerate much higher concentrations of phosphorus and nitrogen than was measured within this investigation. In a study by Kelly \& Whitton (1995), the median content of FRP was $79 \mathrm{mg} \mathrm{m}^{-3}$ and the maximum $2035 \mathrm{mg} \mathrm{m}^{-3}$; in the present study the median of FRP was $26 \mathrm{mg} \mathrm{m}^{-3}$ and the maximum $409 \mathrm{mg} \mathrm{m}^{-3}$ (Table 4). Although here TotP was used instead of FRP in hydrochemical classification, the Spearman correlation between TotP and FRP was very high $(R=0.93, p<0.001)$, and hence these results are comparable. Thus diatoms can stand at least a five-fold higher content of phosphorus than was measured in this study. The water quality varies in a wide range in different European ecoregions. In Finnish rivers, the majority of TotP concentrations are lower than $100 \mathrm{mg} \mathrm{m}^{-3}$, mostly $<50 \mathrm{mg} \mathrm{m}^{-3}$ (Eloranta \& Soininen, 2002), in Iceland they never exceed $50 \mathrm{mg} \mathrm{m}^{-3}$, while in Denmark TotP is higher than $50 \mathrm{mg} \mathrm{m}^{-3}$ in all streams (Nordic Council of Ministers, 1997). As the parameters of water quality are highly different, suitable diatom indices and their limit values for quality classes should be selected for each individual region.

The diversity indices $\mathrm{H}^{\prime}$ and $\mathrm{I}$, and Tax are not suitable as environmental indicators. They tend to have the highest values in intermediate conditions (Fig. 4). Archibald (1972), Lobo et al. (1995), and Jüttner et al. (1996) also stressed that measurement of algal species diversity is not a proper method for evaluating water quality.

Although the ranges of the fluctuation of the values of GDI were among the largest (Table 1), its median values revealed no significant differences (KruskalWallis median test, $p<0.01$ ) either on the scale of water trophy or according to quality classes. The same applied also to IDAP. Hence, these two indices are not fit for evaluating water quality in Estonia. Rott and Epid-D are not suitable for the estimation of the state of a water body either, as neither indicated significant improvement in water quality in the Selja River during five years (Figs. 2, 3). It is not surprising as Rott was developed for Alpine streams and the ecological conditions are highly different in lowland and mountain regions. 

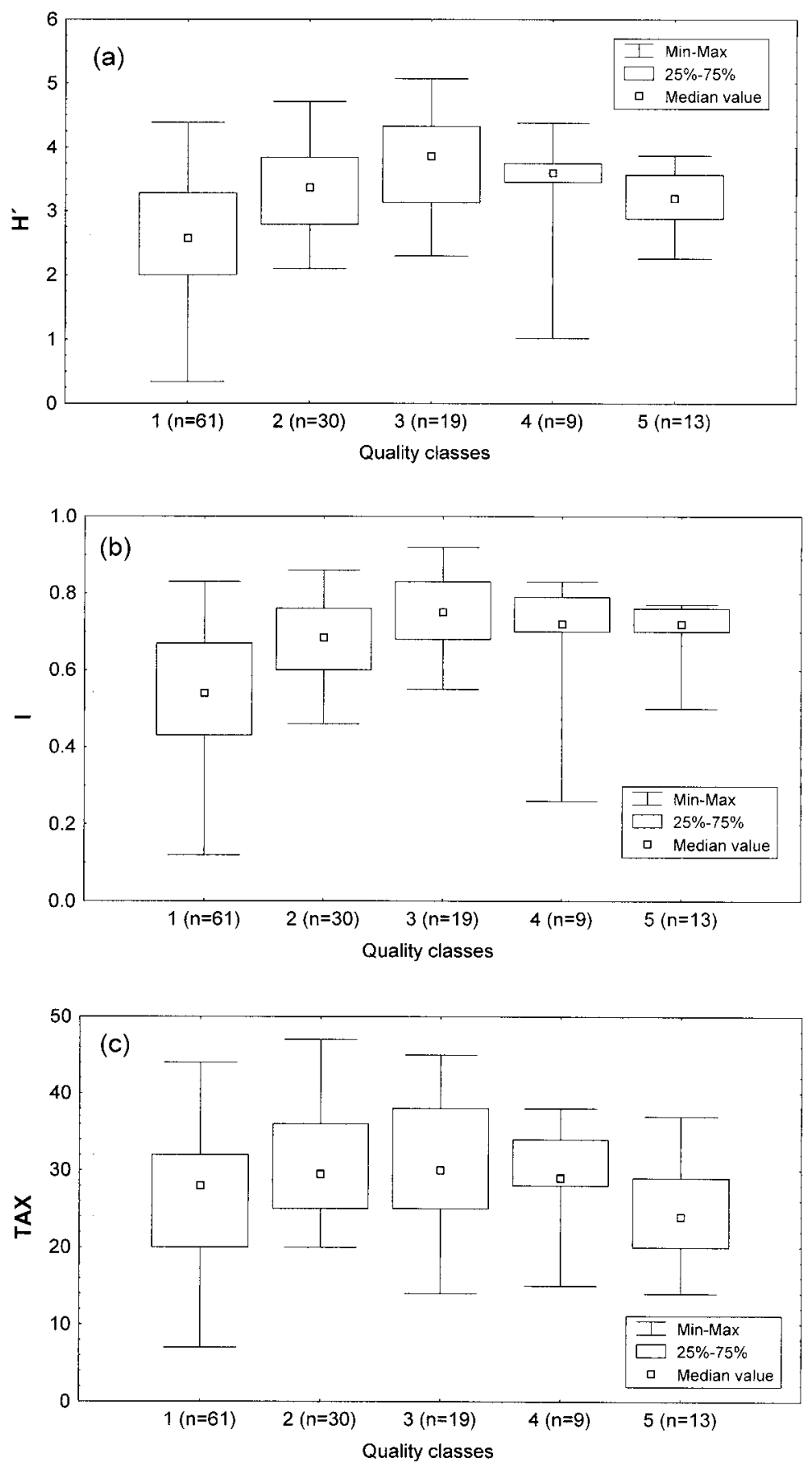

Fig. 4. Differences in the values of (a) Shannon-Weaver diversity $\left(\mathrm{H}^{\prime}\right)$, (b) evenness (I), and (c) species richness (Tax) shown as boxplots by quality classes according to total P (1 - High, 2 - Good, 3 - Moderate, 4 - Poor, 5 - Bad); $\mathrm{n}$ - number of samples. 


\section{CONCLUSIONS}

Of the 16 diatom indices studied 7 ( $\mathrm{H}^{\prime}$, I, Tax, GDI, IDAP, Rott, and Epid-D) proved for different reasons not fit for the evaluation of the ecological status of rivers in Estonia. The remaining 9 were selected for further study. Tests with more polluted waters are needed to establish which index/indices are the most suitable for monitoring Estonian running waters. Then it will be also possible to set the limit values for them.

\section{ACKNOWLEDGEMENTS}

The study was carried out at the Institute of Zoology and Botany of the Estonian Agricultural University. Conductivity, $\mathrm{pH}$, oxygen content in the water, and $\mathrm{BOD}_{5}$ were determined by P. Pall. M. Viik was responsible for the measurements of the concentration of nitrogen and phosphorus compounds and chemical oxygen demand. The research was supported by the Estonian Science Foundation (grant No. 5429).

\section{REFERENCES}

Archibald, R. E. M. 1972. Diversity in some South African diatom associations and its relation to water quality. Wat. Res., 6, 1229-1238.

Descy, J.-P. \& Ector, L. 1999. Use of diatoms for monitoring rivers in Belgium and Luxemburg. In Use of Algae for Monitoring Rivers III (Prygiel, J., Whitton, B. A. \& Bukowska, J., eds.), pp. 128-137. Agaence de 1'Eau Artois-picardie, Douai.

Directive 2000/60/EC of the European Parliament and of the Council of 23 October 2000. 2000. Official Journal of the European Communities, 22.12, 1-72.

Eloranta, P. \& Soininen, J. 2002. Ecological status of some Finnish rivers evaluated using benthic diatom communities. J. Appl. Phycol., 14, 1-7.

Forsberg, C. \& Ryding, S. O. 1980. Eutrophication parameters and trophic status indices in 30 Swedish waste-receiving lakes. Arch. Hydrobiol., 89, 189-207.

Grasshoff, K., Ehrhardt, M. \& Kremling, K. (eds.). 1983. Methods of Seawater Analyses. 2. Verlag Chemie, Weinheim.

Järvekülg, A. 1993. Trophy of the water of Estonian rivers and nutrients limiting the primary production. Water pollution and quality in Estonia. Environ. Rep., 7, 29-34.

Jüttner, I., Rothfritz, H. \& Ormerod, S. J. 1996. Diatoms as indicators of river quality in the Nepalese Middle Hills with consideration of the effects of habitat-specific sampling. Freshwater Biol., 36, 475-486.

Kelly, M. G. 1998. Use of the trophic diatom index to monitor eutrophication in rivers. Water Res., 32(1), 236-242.

Kelly, M. G. \& Whitton, B. A. 1995. A new diatom index for monitoring eutrophication in rivers. J. Appl. Phycol., 7, 433-444.

Kolkwitz, R. \& Marsson, M. 1908. Ökologie der pflanzlichen Saprobien. Ber. Dt. Ges., 26A, 505-519.

Lecointe, C., Coste, M. \& Prygiel, J. 1993. "Omnidia" software for taxonomy, calculation of diatom indices and inventories management. Hydrobiologia, 269/270, 509-513. 
Lobo, E., Katoh, K. \& Aruga, Y. 1995. Response of epilithic diatom assemblages to water pollution in rivers in the Tokyo Metropolitan area, Japan. Freshwater Biol., 34, 191-204.

Loigu, E. \& Leisk, Ü. 2001. Classification of chemical status of rivers. In Environmental Impact and Water Management in a Catchment Area Perspective (Seepõld, M., ed.), pp. 46-53. Tallinn Technical University.

Loopmann, A. 1979. Eesti NSV jõgede nimestik. Valgus, Tallinn.

Nordic Council of Ministers. 1997. Indicators of the State of the Environment in the Nordic Countries. Stougaard Jensen/Scantryk A/S, Copenhagen.

Prygiel, J. \& Coste, M. 1996. Recent trends in monitoring French rivers using algae, especially diatoms. In Use of Algae for Monitoring Rivers II (Whitton, B. A. \& Rott, E., eds.), pp. 87-96. Institut für Botanik, Universität Innsbruck.

Prygiel, J., Whitton, B. A. \& Bukowska, J. (eds.). 1999. Use of Algae for Monitoring Rivers III. Agaence de 1'Eau Artois-picardie, Douai.

Round, F. E. 1991. Diatoms in river water-monitoring studies. J. Appl. Phycol., 3, 129-145.

Vilbaste, S. 2001. Benthic diatom communities in Estonian rivers. Boreal Environ. Res., 6, 191-203.

Vilbaste, S., Sundbäck, K., Nilsson, C. \& Truu, J. 2000. Distribution of benthic diatoms in the littoral zone of the Gulf of Riga, the Baltic Sea. Eur. J. Phycol., 35, 373-385.

Whitton, B. A. \& Rott, E. (eds.). 1996. Use of Algae for Monitoring Rivers II. Institut für Botanik, Universität Innsbruck.

Whitton, B. A., Rott E. \& Friedrich, G. (eds.). 1991. Use of Algae for Monitoring Rivers. Institut für Botanik, Universität Innsbruck.

\section{Ränivetikaindeksite rakendamise võimalustest Eesti vooluvete kvaliteedi määramisel}

\section{Sirje Vilbaste}

On analüüsitud ränivetikaindekseid 21 vooluveekogu 139 lõigust kogutud materjali põhjal. Kasutati OMNIDIA tarkvara, mis arvutab 16 indeksit, arvestades seejuures liikide suhtelist arvukust, iga liigi kuulumist teatud vee kvaliteedi, troofsuse või saproobsuse klassi ja selle indikaatorlikku väärtust teatud skaalal. Paljudes Euroopa riikides on ränivetikaindeksid kasutuses vooluvete kvaliteedi markeritena. Käesolevas töös on analüüsitud nende indeksite tundlikkust vee troofsusastme (oligo-, meso-, eu- ja hüpertroofne) ning kvaliteediklassi (väga hea, hea, rahuldav, halb ja väga halb) suhtes Eesti vooluvetes. Töö tulemusel valiti välja üheksa potentsiaalset indeksit, millega edasi töötada. 